\title{
Dividend Policy pada Perusahaan Perbankan yang Terdaftar Di BEI
}

\author{
Zakaria $^{1}$, Fajar Rina Sejati ${ }^{2}$, Murti Mutia ${ }^{3}$. \\ Universitas Yapis Papua ${ }^{1,2,3}$ \\ zakariahatta@gmail.com
}

\begin{abstract}
Dividend policy is a decision taken by a company related to dividends, whether profits will be distributed to shareholders or investors in the form of dividends or profits will be retained as retained earnings for investment financing in the future. Factors that can influence dividend policy include current ratio, debt to equity ratio, net profit margin, investment opportunity set. The population in this study are banking companies listed on the Indonesia Stock Exchange in the 2015-2018 period. The samples obtained are based on purposive sampling techniques and obtained by 9 companies. The data analysis technique used is multiple linear regression analysis. The analysis shows that the debt to equity ratio, investment opportunity set has a positive effect and net profit margin has a negative effect on the dividend policy. However, the current ratio has no effect on the dividend policy.
\end{abstract}

Keywords: dividend policy, current ratio, debt to equity ratio, net profit margin, investment opportunity set.

\begin{abstract}
ABSTRAK
Kebijakan dividen merupakan sebuah keputusan yang diambil oleh perusahaan terkait dengan dividen, apakah laba akan dibagi kepada pemegang saham atau investor dalam bentuk dividen atau laba akan ditahan sebagai laba yang ditahan untuk pembiayaan investasi di masa yang akan datang. Faktor-faktor yang dapat mempengaruhi dividend policy diantaranya adalah current ratio, debt to equity ratio, net profit margin, investment opportunity set. Populasi dalam penelitian ini adalah Perusahaan perbankan yang terdaftar di Bursa Efek Indonesia periode 2015-2018. Sampel yang diperoleh berdasarkan teknik purposive sampling dan diperoleh 9 perusahaan. Teknik analisis data yang digunakan adalah analisis regresi linear berganda. Hasil analisis menunjukan bahwa debt to equity ratio, investment opportunity set memiliki pengaruh positif dan net profit margin memiliki pengaruh negatif terhadap dividend policy. Akan tetapi, current ratio tidak memiliki pengaruh terhadap dividend policy.
\end{abstract}

Kata Kunci : dividend policy, current ratio, debt to equity ratio, net profit margin, investment opportunity set.

\section{PENDAHULUAN}

Para investor menginginkan pembagian dividen yang relatif stabil, karena dengan adanya stabilitas dividen dapat meningkatkan kepercayaan investor terhadap perusahaan sehingga mengurangi ketidakpastian investor dalam menanamkan dananya di perusahaan tersebut. Dengan demikian, pembagian dividen yang dilakukan perusahaan adalah berdasarkan dividend policy atau biasa 
disebut dengan kebijakan dividen, yang ditetapkan oleh perusahaan dan merupakan hasil dari Rapat Umum Pemegang Saham. Sebelum sebuah perusahaan membagikan dividen dari keuntungannya, terlebih dahulu harus mendapat persetujuan dari mayoritas pemegang saham. Jika mayoritas tidak menyetujui adanya pembagian dividen dan lebih cenderung untuk pengembangan perusahaan, maka manajemen perusahaan tidak perlu membagi dividen walaupun berhasil mencapai keuntungan yang besar.

Isu pertama yang melandasi penelitian ini terjadi pada PT Bank Mandiri Tbk. Melalui Rapat Umum Pemegang Saham yang menyetujui pembagian dividen sebesar 30\% dari laba bersih tahun 2017 serta pemberian dividen tambahan sebesar $15 \%$. Dengan demikian, seluruh dividen yang diterima pemegang saham adalah 45\% dari laba bersih 2017 atau sebesar Rp9,288 triliun setara Rp199,03 per lembar saham. Sisanya sekitar 55\% dari laba bersih 2017 disetujui sebagai laba ditahan (Sandy, 2019).

Isu kedua terjadi pada PT Bank Tabungan Pensiunan Nasional Tbk (BTPN) dan PT Bank Sumitomo Mitsui Indonesia (SMBCI), dimana melalui Rapat Umum Pemegang Saham memutuskan untuk tidak membagikan dividen kepada para pemegang saham untuk tahun buku 2018. Keputusan tersebut dilakukan dalam rangka memperkuat permodalan dan mendukung pertumbuhan perusahaan. Dengan adanya merger BTPN dan SMBCI, maka asetnya lebih besar dan kuat. Salah satu keuntungannya yakni jangkauan BTPN bisa lebih luas dalam menjangkau segmen korporasi dan ritel (Fiansyah, 2019).

Sementara, isu terbaru mengenai Kedua isu tersebut mendorong untuk mengangkat topik mengenai dividend policy di dunia perbankan, dengan menguji faktor-faktor yang dapat mempengaruhi dividend policy dalam suatu perusahaan, diantaranya likuiditas, solvabilitas, profitabilitas, dan kesempatan investasi.

Posisi likuiditas sangat mempengaruhi pembagian dividen suatu perusahaan. Apabila dana tunai perusahaan likuid, maka manajemen perusahaan tidak akan ragu untuk membagikan dividen dalam jumlah besar. Rasio likuiditas dalam penelitian ini diproksikan dengan Current Ratio. Semakin besar current ratio menunjukkan semakin tinggi kemampuan perusahaan dalam memenuhi kewajiban jangka pendeknya (termasuk di dalamnya kewajiban membayar dividen kas yang terutang). Laim dkk., (2015) menemukan bahwa Current Ratio tidak berpengaruh terhadap Dividend Payout Ratio. Sementara, Suryati dan Siagian (2018) menemukan bahwa Current Ratio berpengaruh terhadap Dividend Payout Ratio.

Rasio solvabilitas dalam penelitian diproksikan oleh Debt Equity Ratio (DER). Rasio ini berfungsi untuk mengetahui setiap modal sendiri yang dijadikan untuk jaminan utang (Kasmir 2013). Sebuah perusahaan dapat menentukan kebijakan untuk tidak membagikan dividen, apabila perusahaan tersebut ingin membayar atau melunasi pinjamannya. Sabri dkk (2017) menemukan bahwa DER berpengaruh terhadap Dividend Payout Ratio. Sementara, Suryati dan Siagian (2018) menemukan bahwa DER tidak berpengaruh terhadap Dividend Payout Ratio.

Perusahaan yang memiliki tingkat keuntungan atau profitabilitas yang relatif stabil, seringkali dapat memperkirakan keuntungan yang diperolehnya di kemudian hari. Dengan demikian, perusahaan yang seperti ini kemungkinan besar 
akan membagikan dividen daripada perusahaan yang keuntungannya berfluktuasi. Tingkat profitabilitas dalam penelitian ini diproksikan oleh Net Profit Margin (NPM). Yunita dan Friskarunia (2016) NPM tidak berpengaruh terhadap Dividend Payout Ratio. Sementara, Sabri dkk (2017) NPM berpengaruh terhadap Dividend Payout Ratio.

Investment Opportunity Set (IOS) merupakan keputusan investasi yang dilakukan oleh manajemen perusahaan yang menunjukkan bahwa perusahaan tersebut memiliki pilihan-pilihan atau kesempatan investasi untuk meningkatkan pertumbuhan perusahaan (Abdillah dan Hartono 2018). Perusahaan yang bertumbuh dan cenderung akan membesarkan asetnya akan membutuhkan dana untuk ekspansi perusahaan. Semakin besar asset perusahaan, semakin besar pula dana yang dibutuhkan dalam pengelolaannya, dan semakin besar pula nilai laba yang harus ditahan perusahaan tersebut. Sari dkk (2015) menemukan bahwa Investment Opportunity berpengaruh terhadap Dividend Payout Ratio. Sementara, Yuwono dan Kurniawati (2018) menemukan bahwa Investment Opportunity tidak berpengaruh terhadap Dividend Payout Ratio.

Dengan demikian, yang menjadi rumusan masalah dalam penelitian ini adalah sebagai berikut:

1. Apakah Current Ratio berpengaruh terhadap Dividend Policy?

2. Apakah Debt to Equity Ratio berpengaruh terhadap Dividend Policy?

3. Apakah Net Profit Margin berpengaruh terhadap Dividend Policy?

4. Apakah Investment Opportunity Set berpengaruh terhadap Dividend Policy?

\section{TINJAUAN PUSTAKA DAN PENGEMBANGAN HIPOTESIS Dividend Policy}

Dividend Policy merupakan penggunaan laba bersih setelah pajak yang akan dibagikan kepada para pemegang saham dan berapa besar bagian laba bersih yang akan digunakan untuk membiaya investasi perusahaan. Apabila perusahaan memilih untuk membagikan laba yang diperolehnya dalam bentuk dividen, maka akan mengurangi retained earnings dan selanjutnya mengurangi total sumber dana internal. Sebaliknya, jika perusahaan memilih untuk menahan laba yang diperolehnya, maka kemampuan pembentukan dana internal akan semakin besar.

Dividend Policy yang optimal adalah Dividend Policy yang menciptakan keseimbangan diantara dividen saat ini dan pertumbuhan di masa mendatang sehingga dapat memaksimumkan harga saham perusahaan. Dividend Policy adalah penting karena beberapa alasan. yang pertama, perusahaan dapat menggunakan dividen sebagai alat untuk sinyal keuangan orang luar tentang stabilitas dan prospek pertumbuhan perusahaan. Dan kedua, dividen memainkan peran penting dalam struktur modal perusahaan (Hardiyanto 2014).

\section{Teori Dividend Policy}

Seperti yang dikemukakan oleh (Ressy dan Chariri 2013), bahwa terdapat beberapa pendapat dan teori yang mengemukakan tentang preferensi investor terhadap dividend policy, yaitu
1. The Bird in Hand Theory 
Saham perusahaan akan dihargai lebih tinggi jika dividen harapannya lebih tinggi dibandingkan dengan perusahaan yang dividennya lebih rendah (Gumanti Tatang Ary 2013).

2. Dividend Irrelevance Theory (ketidakrelevanan dividen)

Teori yang menyatakan bahwa kebijakan dividen perusahaan tidak mempunyai pengaruh terhadap nilai perusahaan maupun biaya modalnya. Peningkatan pembayaran dividen hanya dimungkinkan apabila laba yang diperoleh perusahaan juga meningkat. Keuntungan yang diperoleh atas kenaikan harga saham akibat pembayaran dividen akan diimbangi dengan penurunan harga saham karena adanya penjualan saham baru. Oleh karenanya pemegang saham dapat menerima kas dari perusahaan saat ini dalam bentuk pembayaran dividen atau menerimanya dalam bentuk capital gain. Kemakmuran pemegang saham sekali lagi tidak dipengaruhi oleh dividend policy saat ini maupun dimasa datang.

3. Tax Preferance Theory

Teori ini menyatakan bahwa Investor menghendaki perusahaan untuk menahan laba setelah pajak dan dipergunakan untuk pembiayaan investasi dari pada dividen dalam bentuk kas. Oleh karenanya perusahaan sebaiknya menentukan dividen payout ratio yang rendah atau bahkan tidak membagikan dividen. Karena dividen cenderung dikenakan pajak yang lebih tinggi dari pada capital gain, maka investor akan meminta tingkat keuntungan yang lebih tinggi untuk saham dengan dividend policy yang tinggi.

\section{Current Ratio (CR)}

Current ratio (CR) merupakan salah satu bagian dari rasio likuiditas, current ratio (CR) merupakan rasio untuk mengukur kemampuan perusahaan dalam membayar kewajiban jangka pendek atau utang yang segera jatuh tempo pada saat ditagih secara keseluruhan. Dengan kata lain, seberapa banyak aktiva lancar yang tersedia untuk menutupi kewajiban jangka pendek yang segera jatuh tempo. Rasio lancar dapat pula dikatakan sebagai bentuk untuk mengkur tingkat keamanan (margin of safety) suatu perusahaan. Penghitungan rasio lancar dihitung dengan cara membandingkan antara total aktiva lancar dengan total utang lancar.

Dari hasil pengukuran rasio apabila rasio lancar rendah, dapat dikatakan bahwa perusahaan kurang modal untuk membayar utang. Namun, apabila hasil pengukuran rasio tinggi, belum tentu kondisi perusahaan sedang baik. Hal ini dapat terjadi karena kas tidak digunakan sebaik mungkin. Apabila perusahaan memiliki current ratio (CR) yang tinggi memberikan indikasi jaminan yang baik kreditor jangka pendek dalam arti setiap saat perusahaan memiliki kemampuan melunasi kewajiban-kewajiban jangka pendek. Akan tetapi current ratio yang tinggi akan berpengaruh negatif terhadap kemampuan memperoleh laba, karena sebagian modal kerja tidak berputar atau mengalami pengangguran.

\section{Debt to Equity Ratio (DER)}

Debt to Equity Ratio (DER) merupakan salah satu bagian dari rasio Solvabilitas, Debt to Equity Ratio (DER) merupakan rasio yang digunakan untuk menilai utang dengan ekuitas, Rasio ini berguna untuk mengetahui jumlah dana 
yang disediakan kreditor dengan pemilik perusahaan atau untuk mengetahui jumlah rupiah modal sendiri yang dijadikan untuk jaminan uang (Kasmir 2016).

Perusahaan dengan leverage yang besar dapat dipakai manajer sebagai signal yang optimis akan masa depan perusahaan. Myers dan Majluf membuat model signaling theory sebagai kombinasi dari keputusan investasi dan keputusan pendanaan. Manajer diasumsikan mengetahui nilai sebenarnya perusahaan pada masa depan. Di samping itu, manajer juga diasumsikan bertindak sesuai dengan kepentingan dan pemegang saham lama, yaitu orang yang memiliki saham di perusahaan ketika keputusan diambil. Pada umumnya pendanaan dengan utang dianggap sebagai positif sehingga manajer percaya bahwa saham undervalued (Mulyawan 2015).

\section{Net Profit Margin (NPM)}

Net Profit Margin (NPM) merupakan salah satu bagian dari rasio profitabilitas. Net Profit Margin (NPM) merupakan rasio yang menggambarkan tingkat keuntungan yang diperoleh perusahaan dibandingkan dengan pendapatan yang diterima dari kegiatan operasionalnya (Pandia 2012). Rasio ini menunjukkan berapa besar persentase pendapatan bersih yang diperoleh dari setiap penjualan. Menurut (Harahap 2015) semakin besar rasio ini semakin baik karena dianggap kemampuan perusahaan dalam mendapatkan laba cukup tinggi. Rasio ini bisa diinterpretasikan sebagai kemampuan perusahaan menekan biaya-biaya diperusahaan pada periode tertentu.

\section{Investment Opportunity Set (IOS)}

Investment Opportunity Set (IOS) adalah keputusan investasi dalam bentuk kombinasi antara aktiva yang dimiliki (assets in place) dan opsi investasi di masa yang akan datang, di mana kesempatan investasi tersebut akan memengaruhi nilai perusahaan (Jogiyanto 2013). Kesempatan investasi merupakan pilihan investasi masa depan dan mencerminkan adanya pertumbuhan aktiva dan ekuitas.

Dividend policy sangat dipengaruhi oleh peluang investasi dan ketersediaan dana guna membiayai investasi baru. Kegiatan investasi suatu perusahaan akan menentukan keuntungan yang diperoleh perusahaan di masa yang akan datang. IOS merupakan alternatif perusahaan dalam memanfaatkan laba bersih yang dimilikinya. Perusahaan dapat menggunakan laba untuk investasi kembali atau untuk dibagikan dalam bentuk dividen. Apabila perusahaan salah dalam mengambil keputusan investasi, maka kelangsungan hidup perusahaan akan terganggu dan akan mempengaruhi penilaian investor terhadap nilai perusahaan.

\section{Pengembangan Hipotesis}

1. Pengaruh Current Ratio (CR) Terhadap Dividend Policy

Current Ratio (CR), merupakan salah satu ukuran rasio likuiditas yang dihitung dengan membagi aktiva lancar (current assets) dengan hutang/kewajiban (current liability). Semakin besar current ratio menunjukkan semakin tinggi kemampuan perusahaan dalam memenuhi kewajiban jangka pendeknya (termasuk di dalamnya kewajiban membayar dividen kas yang terutang). Jika posisi likuiditas perusahaan kuat maka kemampuan perusahaan membayar dividen adalah besar, mengingat bahwa 
dividen merupakan arus kas keluar bagi perusahaan. Hal ini didukung oleh penelitian (Suryati dan Siagian 2018) bahwa Current Ratio berpengaruh signifikan terhadap Dividend Payout Ratio. Berdasarkan teori-teori yang telah ada maka dapat diajukan hipotesis sebagai berikut:

H1 $_{1}$ Current Ratio (CR) Berpengaruh Terhadap Dividend Policy

\section{Pengaruh Debt to Equity Ratio (DER) Terhadap Dividend Policy}

Debt to Equity Ratio (DER) merupakan keseimbangan proporsi antara aktiva yang didanai oleh kreditor dan yang didanai oleh pemilik perusahaan. Semakin meningkatnya rasio hutang (dimana beban hutang juga semakin besar) maka hal tersebut berdampak terhadap profitablitas yang diperoleh perusahaan, karena sebagian digunakan untuk membayar bunga pinjaman. Dengan biaya bunga yang semakin besar, maka profitabilitas (earnings after tax) semakin berkurang (karena sebagian digunakan untuk membayar bunga), maka hak para pemegang saham (dividen) juga semakin berkurang (Andriyani, 2008) . Hal ini didukung oleh penelitian (Sabri dkk 2017) bahwa DER berpengaruh signifikan terhadap Dividend Payout Ratio. Berdasarkan teori-teori yang telah ada maka dapat diajukan hipotesis sebagai berikut:

$\mathbf{H}_{2}$ : Debt to Equity Ratio (DER) Berpengaruh Terhadap Dividend Policy

\section{Pengaruh Net Profit Margin (NPM) Terhadap Dividend Policy}

Net Profit Margin (NPM) merupakan perbandingan keuntungan/laba bersih perusahaan setelah pajak dengan penjualan (sales). Semakin tinggi rasio ini mengindikasikan semakin baik perusahaan menghasilkan laba bersih, yang artinya kemampuan untuk membayar dividen juga akan semakin tinggi. Hal ini didukung oleh penelitian (Sabri dkk., 2017)bahwa NPM berpengaruh signifikan terhadap Dividend Payout Ratio. Berdasarkan teori-teori yang telah ada maka dapat diajukan hipotesis sebagai berikut:

H3 : Net Profit Margin (NPM) Berpengaruh Terhadap Dividend Policy

\section{Pengaruh Investment Opportunity Set (IOS) Terhadap Dividend Policy}

Investment Opportunity Set (IOS) merupakan nilai kesempatan investasi dan merupakan pilihan untuk membuat investasi dimasa yang akan datang. Perusahaan yang mengalami pertumbuhan akan memilih banyak kesempatan investasi sebagai jalan untuk mengembangkan perusahaan. Pertumbuhan perusahaan dapat dilihat dari pertumbuhan penjualan periode tertentu (sales growth) dan rasio investasi yang semakin besar dilakukan perusahaan pada aset tetap maka akan semakin tinggi kadar investasi yang dilakukan oleh perusahaan. Hal ini didukung oleh penelitian (Sari dkk., 2015) bahwa Investment Opportunity set berpengaruh terhadap Dividend Payout Ratio. Berdasarkan teori-teori yang telah ada maka dapat diajukan hipotesis sebagai berikut:

$\mathrm{H}_{4}$ : Investment Opportunity Set (IOS) Berpengaruh Terhadap Dividend Policy. 


\section{METODE PENELITIAN}

Teknik penentuan sampel yang digunakan adalah purposive sampling. Pemilihan sampel secara purposive sampling dilakukan dengan tujuan untuk memperoleh sampel berdasarkan kriteria yang ditetapkan. Kriteria yang digunakan dalam pengambilan sampel penelitian ini adalah sebagai berikut :

1. Perusahaan yang mempublikasikan laporan tahunan secara lengkap dengan periode pelaporan tahunan yang berakhir pada tanggal 31 Desember.

2. Perusahaan yang membagikan dividen tunai selama 4 tahun berturut-turut periode 2015-2018.

3. Laporan keuangan dinyatakan dalam mata uang rupiah.

4. Laporan keuangan yang mempunyai laba positif.

5. Memiliki kelengkapan informasi yang dibutuhkan terkait dengan indikatorindikator perhitungan yang dijadikan variabel pada penelitian ini.

\section{Tabel 1}

\section{Data Rincian Sampel}

\begin{tabular}{|c|c|c|}
\hline No & Kriteria Sampel & Jumlah \\
\hline $\mathrm{S}$ & Jumlah perusahaan perbankan di BEI periode tahun 2015-2018 & 45 \\
\hline & Dikurangi : & \\
\hline $\mathrm{u}_{1}$ & Perusahaan yang tidak mempublikasikan laporan tahunan secara & \\
\hline $\begin{array}{l}\mathrm{m} \\
\mathrm{b}\end{array}$ & $\begin{array}{l}\text { lengkap dengan periode pelaporan tahunan yang berakhir pada } \\
\text { tanggal } 31 \text { Desember. }\end{array}$ & $(10)$ \\
\hline$e^{2}$ & Perusahaan yang tidak membagikan dividen tunai selama 4 tahun & (26) \\
\hline $\mathrm{r}_{3}$ & $\begin{array}{l}\text { berturut-turut periode } 2015-2018 . \\
\text { Laporan keuangan tidak dinyatakan dalam mata uang rupiah. }\end{array}$ & 0 \\
\hline 4 & Laporan keuangan yang tidak mempunyai laba positif. & 0 \\
\hline 5 & Tidak memiliki kelengkapan informasi yang dibutuhkan terkait & \\
\hline $\mathrm{D}$ & $\begin{array}{l}\text { dengan indikator-indikator perhitungan yang dijadikan variabel pada } \\
\text { penelitian ini. }\end{array}$ & 0 \\
\hline \multicolumn{2}{|c|}{ Jumlah sampel akhir penelitian } & 9 \\
\hline \multicolumn{2}{|c|}{ Bata observasi $=9$ Perusahaan $\times 4$ Tahun } & 36 \\
\hline
\end{tabular}

Sampel yang memenuhi kriteria tersebut adalah 9 perusahaan perbankan yang terdaftar di Bursa Efek Indonesia, dengan 36 data observasi ( 9 x 4 tahun).

Tabel 2

Daftar Sampel Perusahaan Perbankan

\begin{tabular}{|c|c|l|}
\hline NO & KODE & \multicolumn{1}{c|}{ NAMA EMITEN } \\
\hline 1 & AGRO & Bank Rakyat Indonesia Agroniaga Tbk \\
\hline 2 & BBCA & Bank Central Asia Tbk \\
\hline 3 & BBNI & Bank Negara Indonesia (Persero) Tbk \\
\hline 4 & BBRI & Bank Rakyat Indonesia (Persero) Tbk \\
\hline 5 & BDMN & Bank Danamon Indonesia Tbk \\
\hline 6 & BMRI & Bank Mandiri (Persero) Tbk \\
\hline 7 & BNBA & Bank Bumi Arta Tbk \\
\hline 8 & MEGA & Bank Mega Tbk \\
\hline 9 & SDRA & Bank Woori Saudara Indonesia 1906 Tbk \\
\hline
\end{tabular}




\section{Definisi Operasional Variabel Penelitian}

a. Dividend Policy

Dividend Policy dalam penelitian ini diproksikan dengan Dividen Payout Ratio (DPR). DPR adalah rasio antara dividen yang dibayarkan dibandingkan dengan jumlah laba bersih per lembar saham yang diperoleh perusahaan. Besarnya dividend payout ratio dijadikan ukuran oleh para investor yang hendak menanam modal pada saham di bursa efek. Rumus yang akan digunakan untuk mengukur Dividen Payout Ratio adalah sebagai berikut:

$$
\mathrm{DPR}=\frac{\text { Dividen per lembar saham }}{\text { Laba per lembar saham }}
$$

Sumber: Fahmi (2013)

\section{b. $\quad$ Current Ratio (CR)}

Current ratio merupakan perbandingan antara aktiva lancar dengan hutang lancar. Semakin baik Current Ratio, semakin besar kemampuan perusahaaan dalam membayar dividen yang diukur dengan satuan persen (\%). Current Ratio dapat dirumuskan sebagai berikut:

$$
\mathrm{CR}=\frac{\text { Aktiva lancar }}{\text { Hutang lancar }}
$$

Sumber: Hanafi dan Halim (2016)

c. $\quad$ Debt to Equity Ratio (DER)

Debt to Equity Ratio menujukkan perbandingan antara total hutang yang dimiliki perusahaan dengan modal sendiri.. Variabel ini diukur dengan satuan $(\mathrm{X})$ yang diformulasikan sebagai berikut:

$$
\text { DER }=\frac{\text { Total hutang }}{\text { Ekuitas }}
$$

Sumber: Kasmir (2014)

d. $\quad$ Net Profit Margin (NPM)

Net profit margin (NPM) adalah ratio yang digunakan untuk menunjukan kemampuan perusahaan dalam menghasilkan keuntungan bersih setelah dipotong pajak Rumus yang akan digunakan untuk mengukur Net profit margin (NPM) adalah sebagai berikut :

$$
\mathrm{NPM}=\frac{\text { Laba bersih }}{\text { Pendapatan operasional }} \times 100 \%
$$

Sumber: (Kasmir 2012) 
e. $\quad$ Investment Opportunity Set (IOS)

Investment Opportunity Set (IOS) merupakan pilihan investasi di masa mendatang dan merefleksikan adanya perubahan atau pertumbuhan aktiva dan ekuitas. Rumus yang akan digunakan untuk mengukur Investment Opportunity Set adalah sebagai berikut:

$$
M V E B V E=\frac{\text { Jumlah Lembar Saham } \times \text { Harga Penutupan Saham }}{\text { Total Ekuitas }}
$$

Sumber: Kautsar (2014)

\section{Pengujian Asumsi Klasik}

Untuk menghasilkan suatu model yang baik, maka analisis regresi memerlukan pengujian asumsi klasik sebelum melakukan pengujian hipotesis. Pengujian asumsi klasik tersebut meliputi :

a. Uji Normalitas

Uji normalitas data dapat dilakukan dengan menggunakan One Sample Kolmogorov Smirnov yaitu dengan ketentuan apabila nilai signifikan diatas 0,05 maka data terdistribusi normal. Sedangkan jika hasil One Sample Kolmogorov Smirnov menunjukkan nilai signifikan dibawah 0,05 maka data tidak terdistribusi normal.

b. Uji Multikolinieritas

Pengujian multikolinearitas dilakukan dengan melihat nilai Variance Inflation Faktor (VIF) dan korelasi di antara variabel independen. Jika nilai VIF > 10, maka terjadi multikolinearitas di antara variabel independen.

c. Uji Heroskedastisitas

Salah satu cara untuk mengetahui ada tidaknya heteroskedastisitas dalam suatu model regresi linier berganda adalah dengan melihat grafik scatterplot atau nilai prediksi variabel terikat yaitu SRESID dengan residual error yaitu ZPRED. Jika tidak ada pola tertentu dan titik-titik menyebar diatas dan dibawah angka nol pada sumbu y, maka tidak terjadi heteroskedastisitas. Model yang baik adalah yang tidak terjadi heteroskedastisitas (Ghozali 2016).

d. Uji Autokorelasi

Untuk mendeteksi adanya autokorelasi yaitu dengan cara menggunakan uji Durbin-Watson (DW). Salah satu ukuran dalam menentukan ada tidaknya masalah autokorelasi dengan uji Durbin-Watson (DW) menurut (Sunyoto 2013) dengan ketentuan sebagai berikut:

1) Terjadi autokorelasi positif jika nilai DW dibawah -2 atau DW $<-2$

2) Tidak terjadi autokorelasi jika nilai DW berada diantara -2 dan +2 atau $-2<$ DW $<+2$

3) Terjadi autokorelasi negatif jika nilai DW di atas 2 atau DW $>2$.

\section{Analisis Regresi Linier Berganda}

Analisis regresi linier berganda digunakan untuk menguji pengaruh faktorfaktor independen, yaitu Current Ratio (CR), Debt to Equity Ratio (DER), Net Profit Margin (NPM), Investment Opportunity set (IOS) berpengaruh terhadap Dividend Policy Perhitungan regresi linear berganda dihitung sebagai berikut: 


$$
\mathrm{DPR}=\alpha+\beta_{1} \mathrm{CR}+\beta_{2} \mathrm{DER}+\beta_{3} \mathrm{NPM}+\beta_{4} \mathrm{MVEBVE}+\mathrm{e}
$$

Keterangan:

$\begin{array}{ll}\text { DPR } & : \text { Dividend Payout Ratio } \\ \alpha & : \text { Konstanta } \\ \beta_{1}-\beta_{4} & : \text { Koefisien regresi } \\ \text { CR } & : \text { Current Ratio }(\mathrm{CR}) \\ \text { DER } & : \text { Debt to Equity Ratio (DER) } \\ \text { NPM } & : \text { Net Profit Margin (NPM) } \\ \text { MVEBVE } & : \text { Market to Book Value of Equity (MVEBVE) } \\ \text { e } & : \text { Kesalahan residual (error) }\end{array}$

HASIL PENGUJIAN HIPOTESIS

Analisis Statistik Deskriptif

Tabel 3

Statistik Deskriptif

\begin{tabular}{|l|c|c|c|c|}
\hline \multicolumn{1}{|c|}{ Variabel } & Minimum & Maximum & Mean & $\begin{array}{c}\text { Standard } \\
\text { Deviation }\end{array}$ \\
\hline DPR & 2.20 & 8.82 & 6.1399 & 1.60305 \\
\hline CR & 0.08 & 6.04 & 3.5748 & 1.68724 \\
\hline DER & 1.23 & 1.91 & 1.5608 & 0.18063 \\
\hline NPM & -0.98 & 2.26 & 0.4485 & 0.78960 \\
\hline MVEBVE & 2.26 & 8.14 & 5.0080 & 1.09328 \\
\hline $\begin{array}{c}\text { Jumlah Data } \\
\text { Penelitian }\end{array}$ & 36 & 36 & 36 & 36 \\
\hline
\end{tabular}

Berdasarkan Tabel 3 dapat diketahui nilai minimum, nilai maksimum, rata-rata (mean), dan standar deviasi untuk masing-masing variabel. Jumlah keseluruhan data (n) sebanyak 36.

\section{Uji Asumsi Klasik}

\section{a. Uji Normalitas}

Tabel 4

Hasil Uji Normalitas

\begin{tabular}{|cc|c|}
\hline & Jumlah data penelitian & 36 \\
\hline $\mathrm{Z}$ & Kolmogorov-Smirnov & 0.101 \\
\hline & Asymp. Sig. (2-tailed) & 0.200 \\
\hline
\end{tabular}

Berdasarkan Tabel di atas hasil uji normalitas data terlihat bahwa Asymp. Sig. (2-tailed) memiliki nilai 0,200 atau lebih besar dari signifikansi yang 
ditetapkan yaitu sebesar 0,05 atau 5\%. Sehingga dapat disimpulkan bahwa data dalam penelitian ini berdistribusi normal.

b. Uji Multikolinieritas

Tabel 5

Hasil Uji Multikolinieritas

\begin{tabular}{|l|r|r|}
\hline Variabel & $\begin{array}{c}\text { Toleran } \\
\text { ce }\end{array}$ & VIF \\
\hline CR & 0.501 & 1.995 \\
\hline DER & 0.860 & 1.163 \\
\hline NPM & 0.697 & 1.435 \\
\hline MVEBVE & 0.725 & 1.379 \\
\hline
\end{tabular}

Hasil perhitungan pada Tabel 5 menunjukkan bahwa nilai toleransi $>0,1$ dan nilai VIF $<10$, sehingga dapat disimpulkan bahwa tidak terjadi multikolonieritas antar variabel bebas dalam model regresi ini.

\section{c. Uji Heteroskedastisitas}

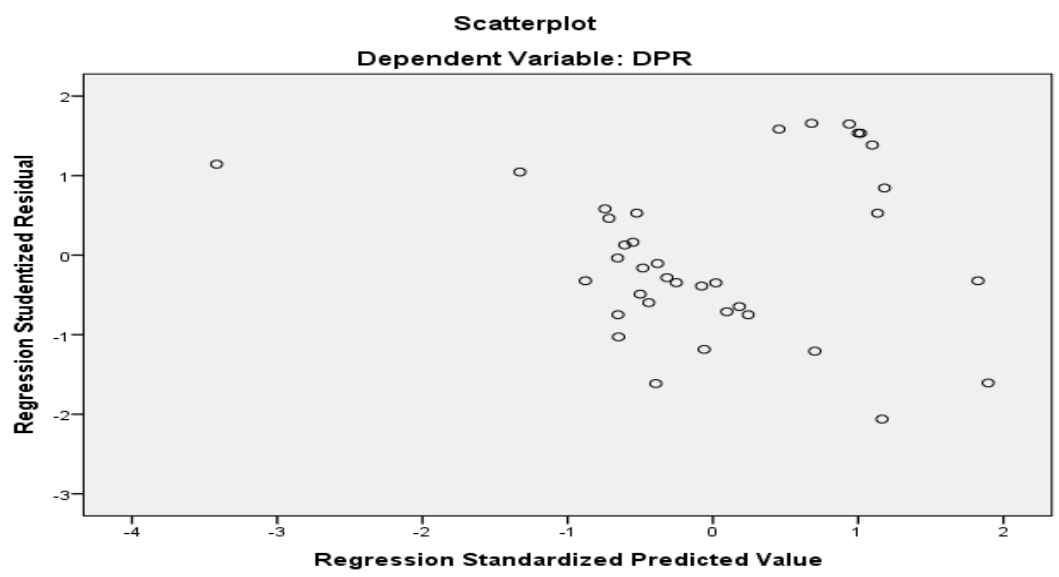

Gambar 1

Hasil Uji Heteroskedasitas: Grafik Scatterplot

Dari gambar 1 menunjukan bahwa grafik scatterplot antara SRESID dan ZPRED menunjukan pola penyebaran, dimana titik-titik menyebar di atas dan di bawah 0 pada sumbu Y. Hal ini menunjukkan bahwa tidak terjadi heteroskedastisitas pada data yang akan digunakan.

\section{d. Uji Autokorelasi}

Tabel 6

Hasil Uji Autokolerasi

\begin{tabular}{|c|}
\hline Durbin-Watson \\
\hline 1.157 \\
\hline
\end{tabular}


Dari hasil pengujian autokolerasi pada persamaan yang digunakan dalam penelitian ini, diperoleh nilai DW sebesar 1.157 angka tersebut diantara -2 sampai +2 maka tidak ada autokolerasi.

\section{Hasil Analisis Regresi Linear Berganda}

Tabel 7

Hasil Analisis Regresi

\begin{tabular}{|l|c|c|c|}
\hline \multicolumn{1}{|c|}{ Variabel } & $\boldsymbol{\beta}$ & $\mathbf{T}_{\text {hitung }}$ & Sig \\
\hline Constant & -3.996 & -2.458 & 0.020 \\
\hline CR & 0.096 & 0.766 & 0.450 \\
\hline DER & 2.913 & 3.255 & 0.003 \\
\hline NPM & -.0889 & -3.907 & 0.000 \\
\hline MVEBVE & 1.127 & 6.998 & 0.000 \\
\hline \multirow{2}{*}{ Uji F } & $\mathrm{F}_{\text {hitung }}$ & \multicolumn{2}{c|}{20.830} \\
\cline { 2 - 5 } & Sig & \multicolumn{2}{c|}{0.000} \\
\hline Adjusted $\mathrm{R}^{2}$ & \multicolumn{3}{|c}{0.694} \\
\hline
\end{tabular}

Berdasarkan Tabel 7 kolom $\beta$ (beta), maka model regresi linear berganda didapat di bentuk adalah sebagai berikut:

$\mathrm{DPR}=-3,996+0,096 \mathrm{CR}+2,913 \mathrm{DER}-0,889 \mathrm{NPM}+1,127 \mathrm{MVEBVE}+\mathrm{e}$

a. Nilai a ( Constant) adalah sebesar -3,996 menyatakan bahwa jika nilai Current Ratio (CR), Debt to Equity Ratio (DER), Net Profit Margin (NPM), Investment Opportunity Set (IOS) konstan atau tidak ada atau sebesar 0, maka besarnya nilai variabel dividend policy sebesar $-3,996$.

b. Nilai koefisien $\beta_{1} \mathrm{CR}=0,096$ menyatakan bahwa ketika nilai Current Ratio naik sebesar 1 satuan, maka nilai dividend policy akan naik sebesar 0,096 poin dengan syarat variabel yang lainnya konstan.

c. Nilai koefisien $\beta_{2}$ DER $=2,913$ menyatakan bahwa ketika nilai Debt to Equity Ratio naik sebesar 1 satuan, maka nilai dividend policy akan naik sebesar 2,913 poin dengan syarat variabel yang lainnya konstan.

d. Nilai koefisien $\beta_{3}$ NPM $=-0,889$ menyatakan bahwa ketika nilai Net Profit Margin naik sebesar 1 satuan, maka nilai dividend policy akan berkurang sebesar 0,889 poin dengan syarat variabel yang lainnya konstan.

e. Nilai koefisien $\beta_{4}$ MVEBVE $=1,127$ menyatakan bahwa ketika nilai Investment Opportunity Set naik sebesar 1 satuan, maka nilai dividend policy akan naik sebesar 1,127 poin dengan syarat variabel yang lainnya konstan. 


\section{Pengujian Hipotesis}

a. Pengaruh Current Ratio (CR) Terhadap Dividend Policy

Berdasarkan hasil uji parsial variabel current ratio menunjukkan $\mathrm{t}$ hitung sebesar 0,776. Sementara nilai $t$ tabel 1,696 sehingga $t$ hitung $<t$ tabel $(0,776<$ 1,696) dengan probabilitas signifikan sebesar 0,450>0,05 maka hipotesis 1 ditolak berarti tidak berpengaruh antara current ratio dengan variabel dividend policy.

b. Pengaruh Debt to Equity Ratio (DER) Terhadap Dividend Policy

Berdasarkan hasil uji parsial variabel debt to equity ratio menunjukkan $\mathrm{t}$ hitung sebesar 3,255. Sementara nilai $t$ tabel 1,696 sehingga $t$ hitung $>t$ tabel $(3,255>1,696)$ dengan probabilitas signifikan sebesar $0,003<0,05$ maka hipotesis 2 diterima berarti berpengaruh positif antara debt to equity ratio dengan variabel dividend policy.

c. Pengaruh Net Profit Margin (NPM) Terhadap Dividend Policy

Berdasarkan hasil uji parsial variabel net profit margin menunjukkan $\mathrm{t}$ hitung sebesar $-3,907$. Sementara nilai $t$ tabel 1,696 sehingga $t$ hitung $>t$ tabel $(-3,907>$ 1,696) dengan probabilitas signifikan sebesar $0,000<0,05$ maka hipotesis 3 diterima berarti berpengaruh negatif antara net profit margin dengan variabel dividend policy.

d. Pengaruh Investment Opportunity Set (IOS) Terhadap Dividend Policy Berdasarkan hasil uji parsial variabel investment opportunity set menunjukkan $t$ hitung sebesar 6,998. Sementara nilai $t$ tabel 1,696 sehingga $t$ hitung $>\mathrm{t}$ tabel $(6,998>1,696)$ dengan probabilitas signifikan sebesar 0,000 < 0,05 maka hipotesis 4 diterima berarti berpengaruh positif antara investment opportunity set dengan variabel dividend policy.

\section{Pengaruh Current Ratio (CR) Terhadap Dividend Policy}

Hasil Perekonomian yang tidak stabil mengakibatkan pasar modal global menghadapi krisis dan ketidakpastian likuiditas yang mengakibatkan melemahnya nilai rupiah terhadap US dollar yang berdampak pada perusahaan perbankan di Indonesia. Perusahaan akan menggunakan dana untuk keperluan operasi perusahaan dan menunda pembayaran deviden. Temuan ini memberikan bukti bahwa investor tidak mempertimbangkan besar kecilnya current ratio tidak berarti mempengaruhi besar kecilnya pembayaran dividen. Hal ini dikarenakan current ratio bukan digunakan untuk membayar dividen tetapi dialokasikan pada pembelian aktiva tetap atau aktiva lancar yang permanen, guna memanfaatkan kesempatan investasi yang ada serta untuk biaya operasional. Akan tetapi, tidak sejalan dengan teori yang diungkapkan oleh Keown dkk., (2000) yang menyatakan bahwa current ratio sangat mempengaruhi pembayaran dividen karena dividen dibayarkan oleh kas yang merupakan bagian dari likuiditas.

Hasil penelitian ini sejalan dengan penelitian yang dilakukan Laim dkk., (2015) yang menyatakan current ratio tidak berpengaruh terhadap dividend payout ratio. 


\section{Pengaruh Debt to Equity Ratio (DER) Terhadap Dividend Policy}

Hal ini menunjukkan bahwa semakin tinggi tingkat debt to equity ratio akan berakibat pada semakin tingginya kemampuan untuk membayarkan dividen. Walaupun besarnya debt to equity ratio tinggi, perusahaan bisa jadi tetap membayarkan dividen yang tinggi kepada investor agar perusahaan dianggap masih mempunyai prospek yang bagus, sehingga investor akan tetap menanamkan modalnya. Komitmen perusahaan untuk melakukan pembayaran dividen secara teratur menyebabkan kemampuan pembayaran dividen tidak dipengaruhi oleh besar kecilnya utang perusahaan bahkan kenaikan utang dapat meningkatkan kemampuan perusahaan membayar dividen selama penggunaan utang diiringi dengan peningkatan laba perusahaan. Akan tetapi tidak sejalan dengan teori yang diungkapkan oleh Andriyani (2008) yang menyatakan bahwa semakin meningkatnya rasio hutang maka hak para pemegang saham yaitu berupa dividen juga semakin berkurang.

Hasil penelitian ini sejalan dengan penelitian yang dilakukan Sabri dkk., (2017) yang menyatakan bahwa debt to equity ratio berpengaruh terhadap dividend payout ratio.

\section{Pengaruh Net Profit Margin (NPM) Terhadap Dividend Policy}

Setiap peningkatan nilai net profit margin maka pada umumnya akan terjadi pula peningkatan pada nilai dividen, namun ada kecenderungan apabila perusahaan tidak membagikan laba dalam bentuk dividen dengan pertimbangan untuk menahan sebagian labanya. Hal ini menunjukkan bahwa semakin tinggi tingkat net profit margin suatu perusahaan akan berakibat pada semakin rendahnya kemampuan perusahaan untuk membayarkan dividen, dan lebih banyak menyimpan laba bersih sebagai laba ditahan yang dapat digunakan untuk operasional perusahaan dan diharapkan dapat meningkatkan laba perusahaan dimasa yang akan datang. Namun dalam teori (Probosari 2011) menyatakan bahwa semakin tinggi net profit margin mengindikasikan bahwa semakin baik perusahaan menghasilkan laba sehingga semakin tinggi pula porsi dividen yang dapat dibayarkan oleh perusahaan.

Hasil penelitian ini sejalan dengan penelitian yang dilakukan Sabri dkk., (2017) yang menyatakan bahwa net profit margin berpengaruh terhadap dividend payout ratio.

\section{Pengaruh Investment Opportunity Set (IOS) Terhadap Dividend Policy}

Investment opportunity set dapat menjadi pemikiran sebagai prospek pertumbuhan bagi perusahaan di masa depan. Kesempatan investasi atau investment opportunity set yang tinggi di masa depan membuat perusahaan dikatakan mempunyai tingkat pertumbuhan yang tinggi. Untuk meningkatkan pertumbuhan tersebut, perusahaan cenderung menggunakan dana yang berasal dari sumber internal dibandingkan dengan sumber eksternal (penerbitan saham atau obligasi). Sumber dana internal lebih disukai untuk membiayai kegiatan reinvestasi karena dana tersebut memiliki risiko dan biaya yang lebih rendah. Menurut (Muliyaningsih, 2016) menyatakan bahwa hubungan positif antara investment opportunity set dengan dividend policy disebabkan karena perusahaan yang mempunyai kesempatan investasi yang positif akan tetap membayarkan 
dividen kepada pemegang sahamnya. Dana yang ada akan digunakan perusahaan untuk membayar dividen dan juga untuk investasi karena keduanya merupakan hal yang sama-sama pentingnya. Perusahaan akan membagi porsi dana untuk keduanya agar antara pembayaran dividen dan investasi sama-sama dapat dipenuhi.

Hasil penelitian ini sejalan dengan penelitian yang dilakukan dilakukan oleh Sari dkk., (2015) yang menyatakan bahwa investment opportunity set erpengaruh terhadap dividend payout ratio.

\section{KESIMPULAN, KETERBATASAN DAN SARAN}

Penelitian ini betujuan untuk menguji pengaruh Current Ratio, Debt Equity Ratio, Net Profit Margin, dan Investment Opportunity Set terhadap Dividend Policy pada perusahaan Perbankan yang terdaftar di Bursa Efek Indonesia (BEI) periode 2015-2018. Jumlah sampel dalam penelitian ini yaitu terdapat 9 perusahaan dalam kurun waktu 4 (empat) tahun sehingga diperoleh sebanyak 36 sampel penelitian. Berdasarkan pengujian hipotesis, dapat disimpulkan:

a. Current Ratio tidak berpengaruh terhadap Dividend Policy;

b. Debt Equity Ratio berpengaruh positif terhadap Dividend Policy;

c. Net Profit Margin berpengaruh negatif terhadap Dividend Policy;

d. Investment Opportunity Set berpengaruh positif terhadap Dividend Policy.

Penelitian ini dilakukan dengan berbagai keterbatasan yang mempengaruhi hasil penelitian. Pertama, hasil penelitian dari Current Ratio tidak terdapat pengaruh terhadap Dividend Policy. Hal tersebut disebabkan karena nilai Current Ratio dalam perusahaan perbankan memiliki nilai mean sebesar 3.5748, sehingga dapat dinyatakan bahwa Current Ratio besar. Dengan nilai Current Ratio yang lebih dari 3,0, mengindikasikan perusahaan sampel tidak dapat mengalokasikan aktiva lancarnya secara optimal dan efisien, sehingga menyebabkan adanya suatu masalah dalam mengelola modal kerja. Dengan adanya perubahan rasio lancar tidak akan mempengaruhi pembagian dividen.

Kedua, dapat diketahui ternyata net profit margin berpengaruh negatif terhadap Dividend Policy. Hal ini berarti kenaikan laba mempengaruhi keputusan manajer dalam menurunkan jumlah dividen yang dibayarkan perusahaan.

Berdasarkan hasil penelitian yang telah dilakukan peneliti memberikan saran untuk peneliti selanjutnya yang akan menggunakan variabel profitabilitas agar menggunakan proksi selain Net Profit Margin, karena hal tersebut akan mempengaruhi hasil penelitian.

Bagi perusahaan, untuk memperhatikan lagi tingkat aktiva lancar yang dimiliki. Dengan pengelolaan aktiva lancar yang efektif dan optimal diharapkan dapat mempengaruhi tingkat pembagian dividen yang relative stablil.

\section{REFERENCES}

Abdillah, W, dan J Hartono. 2015. Partial Least Square (PLS) Alternatif Structural Equation Modeling (SEM) dalam Penelitian Bisnis. Yogyakarta: Andi.

Andriyani, Maria. 2008. "Analisis Pengaruh Cash Ratio, Debt to Equity Ratio, Insider Ownership, Investment Opportunity Set, dan Profitability terhadap Kebijakan Dividen” Skripsi Universitas Diponegoro, Semarang. 
Fahmi, Irham. 2013. Analisis Laporan Keuangan. Bandung: Alfabeta.

Fiansyah, Rahmat. Laba Ditahan Btpn Tidak Bagi Dividen Tahun Ini. https://www.inews.id/finance/bisnis/laba-ditahan-btpn-tidak-bagi-dividentahun-ini. (accessed 16 Februari 2019).

Ghozali, Imam. 2013. Aplikasi Analisis Multivariate dengan Program SPSS. Edisi Ke-7. Semarang: Badan Penerbit Universitas Diponegoro. https://doi.org/10.1017/CBO9781107415324.004.

Ghozali, Imam. 2016. Aplikasi Analisis Multivariate dengan Program IBM SPSS 23.

Ghozali, Imam. 2016. Aplikasi Analisis Multivariete Dengan Program IBM SPSS 23 (Edisi 8). Cetakan ke VIII. Penelitian. Edisi ke-8. Semarang: Badan Penerbit Universitas Diponegoro. https://doi.org/10.1021/o17029646.

Gumanti Tatang Ary. 2013. Kebijakan Dividen Teori, Empiris, dan Implikasi. Jakarta: UPP STIM YKPN.

Halim, Abdul. 2015. Auditing (Dasar-dasar Audit Laporan Keuangan). Edisi Ke5. Yogyakarta: UPP STIM YKPN.

Hanafi, Mamduh, dan Abdul Halim. 2016. Analisis Laporan Keuangan. Edisi Ke5. Yogyakarta: UPP STIM YKPN.

Harahap, Sofyan Syafri. 2015. Analisis Kritis atas Laporan Keuangan. Edisi 1-10. Jakarta: Rajawali Pers. https://doi.org/10.5151/cidi2017-060.

Hardiyanto. 2014. Manajemen Peserta Didik; Berbasis Karakter. Jakarta: Bumi Aksara.

Hery. 2015. Analisis Laporan Keuangan. Edisi Ke-1. Yogyakarta: Center For Academic Publishing Services. https://doi.org/10.5151/cidi2017-060.

Jogiyanto, Hartono. 2013. Teori Portofolio dan Analisis Investasi (Edisi ke 10). Yogyakarta:BPFE. Edisi ke-8. Yogyakarta: BPFE Yogyakarta. https://doi.org/10.1145/3132847.3132886.

Junaedi, Fajar. 2013. Komunikasi Massa Pengantar Teoritis. Yogyakarta: Santusta.

Kasmir. 2012. Analisis Laporan Keuangan. Jakarta: PT. Raja Grafindo Persada.

Kasmir. 2013. Analisis Laporan Keuangan Analisis Laporan Keuangan. Edisi ke1. Jakarta: Pers, Rajawali. https://doi.org/10.1017/CBO9781107415324.004.

Kasmir. 2014. Analisis Laporan Keuangan. Edisi ke-1. Jakarta: PT Raja Grafindo Persada. https://doi.org/10.1016/j.cell.2009.01.043.

Kasmir. 2016. Analisis Laporan Keuangan. Jakarta: Raja Grafindo Persada. https://doi.org/https://doi.org/10.3929/ethz-b-000238666.

Kautsar, Achmad. 2014. "Pengaruh Return On Equity, Debt To Equity Ratio, Invesment Opportunity, Dan Inflasi Terhadap Dividend Payout Ratio Pada Perusahaan Property and Real Estate yang Listed di BEI Tahun 20062009." Bisnis Dan Manajemen 7 (31): 154-66. https://doi.org/10.1002/nme.607.

Kieso, Donald E., Jerry J. Weygandt, dan Terry D. Warfield. 2013. Akuntansi Intermediete Terjemahan Emil Salim. Edisi Kesepuluh Jilid 1. Jakarta: Erlangga

Laim, Wisriati, Sientje C Nangoy, dan Sri Murni. 2015. “Analisis Faktor-Faktor Yang Mempengaruhi Dividend Payout Ratio Pada Perusahaan Yang 
Terdaftar Di Indeks Lq-45 Bursa Efek Indonesia.” Jurnal EMBA 3 (1): $1129-40$.

Lioew, Alfian Meykel, Sri Murni, dan Yunita Mandagie. 2014. "ROA,ROE Pengaruhnya Terhadap Dividend Payout Ratio Pada Perusahaan Perbankan Dan Financial Institusi Yang Terdaftar Di BEI Periode 20102012." Jurnal EMBA 2 (2): 1406-16.

Muliyaningsih, Ratnasari. 2016. "Pengaruh Profitabilitas, Free Cash Flow, Investment Opportunity Set dan Risiko Terhadap Kebijakan Dividen." Skirpsi S1 Universitas Muhammadiyah Yogyakarta.

Mulyawan, Setia. 2015. Manajemen Keuangan. Bandung: CV Pustaka Setia. https://doi.org/10.1017/CBO9781107415324.004.

Murhadi, Werner R. 2013. Analisis Laporan Keuangan, Proyeksi dan Valuasi Saham. Jakarta: Salemba Empat.

Nuryaman, V. C. 2015. Metodologi Penelitian Akuntansi dan Bisnis. Bandung: PT Refika Aditama Anggota Ikapi.

Pandia, Frianto. 2012. Manajemen Dana dan Kesehatan Bank. Jakarta: Rineka Cipta Wahyudi.

Prastowo Andi. 2014. Metode Penelitian Kualitatif dalam Perspektif Rancangan Penelitian. Yogyakarta: Ar-Ruzz Media.

Probosari, Galuh Kusumo. 2011. "Analisis Pengaruh NPM, Quick Ratio, DER, Sales Growth dan Size Terhadap Dividend Payout Ratio." Skripsi Program Sarjana Fakultas Ekonomi, Universitas Diponegoro Semarang.

Rahmadi, Zara Tania. 2018. "Analisis Faktor-Faktor Yang Mempengaruhi Dividend Payout Ratio (DPR) Di Perusahaan Go Publick Yang Terdaftar Di Bursa Efek Indonesia Selain Jasa Keuangan Dengan Model Vector Autoregressive Periode 2009-2013." REKAMAN (Jurnal Riset Ekonomi Bidang Akuntansi dan Manajemen) 2 (1): 165-73.

Ressy, Aggy Eka, dan Anis Chariri. 2013. "Pengaruh Kinerja Keuangan terhadap Kebijakan Dividen di Bursa Efek Indonesia." Diponegoro Journal Of Accounting 2 (4): 1-10.

Rudianto. 2013. Akuntansi Manajemen Informasi untuk Pengambilan Keputusan Strategis. Jakarta: Erlangga .

Sabri, Fitri Handayani, Dwi Risma Deviyanti, dan Indra Suyoto Kurniawan. 2017. "Pengaruh kinerja keuangan terhadap dividend payout ratio studi empiris pada perusahaan BUMN." Kinerja 14 (1): 24-30. https://doi.org/10.29264/jkin.v14i1.2446.

Samrotun, Yuli Chomsatu. 2015. "Kebijakan Dividen Dan Faktor-faktor Yang Memepengaruhinya." Jurnal Paradigma 13 (1): 92-103. https://doi.org/10.33558/jrak.v8i1.882.

Sandy, K. Bank Mandiri Bagi Dividen Rp. 928 Triliun .https://economy.okezone.com/read/2019/03/22/278/2033478/bankmandiri-bagi-dividen-rp9-28-triliun. (accessed 16 Mei 2019).

Sari, Revani Ratna, Harjum Muharam, dan Syuhada Sofyan. 2015. "Analisis Pengaruh Investment Opportunities, Leverage, Risiko Pasar dan Firm Size Terhadap Dividend Policy." Fakultas Ekonomika dan Bisnis Universitas Diponegoro. Universitas Diponegoro. http://eprints.undip.ac.id/49091. 
Sejati, Fajar Rina. 2014. “Analisis Pengaruh Efisiensi Modal Kerja Dan Likuiditas Terhadap Profitabilitas (Kasus Pada Industri Barang Konsumsi Yang Terdaftar Di Bursa Efek Indonesia)." Jurnal Manajemen Dan Akuntansi 2 (1): 1-11. $\quad$ http://journal.stiei-kayutangibjm.ac.id/index.php/jibk/article/view/88.

Sugiyono. 2010. Metode Penelitian Pendidikan Pendekatan Kuantitatif, kualitatif, dan $R \& D$. Bandung: Alfabeta.

Sugiyono. 2014. Metode Penelitian Pendidikan Pendekatan Kuantitatif, Kualitatif, dan R\&D. Bandung: Alfabeta.

Sugiyono. 2015. Metode Penelitian Kombinasi (Mix Methods). Bandung: Alfabeta.

Sunyoto, Danang. 2013. Metodologi Penelitian Akuntansi. Bandung: PT Refika Aditama Anggota Ikapi.

Suryati, Deti, dan Arifin Siagian. 2018. "Analisis Pengaruh Current Ratio, Debt To Equity Ratio, Dan Return On Assets Terhadap Dividend Payout Ratio Pada Perusahaan Manufaktur Yang terdaftar Di BEI Periode 2014-2016." Jurnal Ilmiah Satya Negara Indonesia 11 (2): 1-11. https://doi.org/10.22201/fq.18708404e.2004.3.66178.

Tatang Ary Gumanti. 2013. Kebijakan Dividen Teori Empiris Dan Implikasi. Jakarta: UPP STIM YKPN.

Usman, Halim, dan Sri Wahyuni Mustafa. 2014. "Pengaruh CR, DER Dan ROA Terhadap Dividend Payout Ratio Pada Beberapa Perusahaan Pertambangan Yang Terdaftar di BEI ( 2011-2013 ).” Jurnal Akuntansi 1 (2): 43-47.

Yasa, Kadek Dwi Mahendra; Wirawati, dan Ni Gusti Putu. 2016. "Pengaruh Net Profit Margin,Current Ratio,Dan Debt To Equity Ratio Pada Dividend Payout Ratio." E-Jurnal Akuntansi Universitas Udayana 16 (2): 921-50. https://ojs.unud.ac.id/index.php/Akuntansi/article/view/16463.

Yunita, Nur Afni, dan Nova Friskarunia. 2016. "Pengaruh Kebijakan Hutang , Earning Per Share, Net Profit Margin Dan Profitabilitas Terhadap Dividend Payout Ratio Pada Perusahaan Yang Terdaftar Di LQ45 Periode 2010-2014." Jurnal Akuntansi dan Keuangan 4 (1): 129-46.

Yuwono, Wahyu, Indah Kurniawati, Universitas Ahmad Dahlan, dan Universitas Ahmad Dahlan. 2018. "Faktor-Faktor Yang Mempengaruhi Dividend Payout Ratio (Studi Pada Perusahaan Manufaktur Indonesia)." Jurnal REKSA: Rekayasa Keuangan, Syariah, dan Audit 5 (1): 11-21. 